In our experience the onset of the vascular lesion does not give rise to the alarming signs associated with cellular rejection (toxic syndrome). Accordingly we have been unable to reverse the rejection process because it has been well established by the time signs of renal failure have occurred.

In our whole series of 13 cases the longest survivals have received $x$-irradiation and the shortest survivals immunosuppressive drugs.

We are grateful to Sir Billy Butlin for a gift which has covered some of the expenses involved in this work.

ADDENDUM.- Since the paper was prepared for press another patient with kidney transplantation has died. The cause of death was haemorrhage from the arterial anastomosis on the 25 th post-operative day.

Splenectomy was performed and he was given daily $4 \mathrm{mg}$. of azathioprine (Imuran) per $\mathrm{kg}$. and $60 \mathrm{mg}$. of prednisone ; actinomycin $\mathrm{C}$ was given at intervals. The function of this kidney up until death appeared to be normal (blood urea 40 mg. $/ 100 \mathrm{ml}$.) and only persistent infection gave cause for concern. On histological examination of the kidney, however, there was definite evidence that early widespread rejection vascular disease had developed without giving rise to a rejection crisis.

The vessels of the transplanted kidney showed subendothelial cellular infiltration and focal medial necrosis. The lesions affected interlobar, arcuate, and interlobular arteries and afferent arterioles about equally. Our earlier statement that the interlobulars are always most severely affected needs revising. There was also focal destruction of small groups of tubules apparently by a process of cellular rejection. This is the second case in our series which shows signs of both cellular and vascular types of rejection. The severity of the vascular lesions was a little greater than that of Case 1 (J.F.), but was less than the other three cases surviving for 20-30 days.

\section{REFERENCES}

Dempster, W. J. (1953a). Acta med. scand., 144, 360.

(1953b). Arch. int. Pharmacodyn., 95, 253.

(1957). An Introduction to Experimental Surgical Studies. Blackwell, Oxford.

(1964). In preparation.

Galle, P., and Montera, H. de (1962). Rev. franç. Etud. clin. biol., 7, 40 .

Goodwin, W. E., Kaufman, J. J., Mims, M. M., Turner, R. D., Glassock, R., Goldman, R., and Maxwell, M. M. (1963). Y. Urol., 89, 13.

Hamburger, J., Vaysse, J., Crosnier, J., Auvert, J., Lalanne, C. M., and Hopper, J. (1962). Amer. f. Med., 32, 854 .

Hopper, J. Tubiana, M., Lalanne, C. M., Antoine, B., Auvert, J., Soulier, J. P., Dormont, J., Salmon, C., Maisonnet, M., and Amiel, J. L. (1959). Presse méd., 67, 1771.

Hume, D. M., Merrill, J. P., Miller, B. F., and Thorn, G. W. (1955). f. clin. Invest., 34, 327 .

Kountz, S. L., Williams, M. A., Williams, P. L., Kapros, C., and Dempster, 'W. J. (1963). Nature (Lond.), 199, 257.

K. Laub, D. R., and Cohn, R. (1964). ₹. Amer. med. Ass. In press.

üss, R., Legrain, M., Mathé, G., Nedey, R., and Camey, M. (1962). Rev. franç. Etud. clin. biol., 7, 1048.

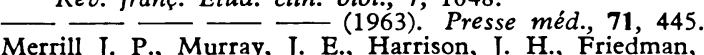

Merrill J. P., Murray, J. E., Harrison, J. H., Friedman, E. A., Dealy, J. B., and Dammin, G. J. (1960). New Engl. f. Med., 262, 1251 . - Takacs, F. J., Hager, E. B., Wilson, R. E., and Dammin, G. J. (1963). F. Amer. med. Ass., 185, 347.

Michon, L., Hamburger, J., Oeconomos, N., Delinotte, P., Richet, G., Vaysse, J., and Antoine, B. (1953). Presse méd., 61, 1419.

Murray, J. E. (1964). Transplantation, 2, 147.

- Merrill, J. P., Harrison, J. H., Wilson, R. E., and Dammin, G. J. (1963). New Engl. 7. Med., 268, 1315.

Nemeth, A., Petri, G., Gal, G. Y., Fazekas, S., Altoriay, T., Scultety, S., Balogh, E., and Karpati, F. (1963). Orv. hetil., 104, 2017.

Parsons, F. M., Markland, C., Raper, F. P., and Fox, M. (1963). Brit. med. F., 1, 930.

Porter, K. A., Thomson, W. B., Owen, K., Kenyon, J. R., Mowbray, J. F., and Peart, W. S. (1963). Ibid., 2, 639.

- Peart, W. S., Kenyon, J. R., Joseph, N. H., Hoehn, R. J., and Calne, R. Y. (1964). N. Y. Acad. Sci. In press.

Shackman, R., Dempster, W. J., and Wrong, O. M. (1963). Brit. F. Urol., 35, 222.

Simonsen, M., Buemann, J., Gammeltoft, A., Jensen, F., and Jørgensen, K. (1953). Acta path. microbiol. scand., 32, 1.

Starzl, T. E., Marchioro, T. L., and Waddell, W. R. (1963). Surg. Gynec. Obstet., 117, 385.

Tyler, H. M., Williams, M. A., and Dempster, W. J. (1964). Nature (Lond.), 201, 84.

Woodruff, M. F. A., Robson, J. S., Nolan, B., Lambie, A. T., Wilson, T. I., and Clark, J. G. (1963). Lancet, 2, 675.

\title{
Study of Renal Vessels by Microdissection in Human Transplantation*
}

\author{
E. M. DARMADY, $\dagger$ M.D., F.R.C.P., F.C.PATH. ; J. M. OFFER, $\dagger$ B.SC. ; FAY STRANACK, $\dagger$ PH.D.
}

[With Special Plate]

Brit. med. F., 1964, 2, 976-978

Renal changes following transplantation would seem to fall into two groups: those which follow closely upon transplantation (5-19 days) and those which survive initial stages and subsequently develop vascular changes.

The histological appearances have been fully described elsewhere (Dempster, 1953 ; Hume et al., 1955 ; Darmady et al., 1955 ; Küss et al., 1962 ; Hamburger et al., 1963 ; Murray et al., 1962, 1963 ; Porter et al., 1963 ; Calne et al., 1963). In the first group the outstanding changes have been necrosis of the tubular epithelium of the first part of the proximal convoluted tubules, and later spreading to the remainder of the tubule. At the same time there appears a patchy round-cell infiltration consisting of lymphocytes, histiocytes, and plasma cells with pyronin-positive material in the cytoplasm, and, in the second

* Based on a lecture given by invitation at a Symposium on Renal Transplantation at the British Postgraduate Medical School, London, 26 April 1963.

†From Portsmouth and Isle of Wight Area Pathological Service. group, proliferation of the vascular intima, degeneration of media, and aneurysmal dilatation with interstitial fibrosis and tubular atrophy.

In this communication we propose to demonstrate by microdissection the extent of these changes and to suggest that vascular lesions which may be observed in the kidney after transplantation occur earlier and more often than previously thought.

\section{Method and Material}

The kidneys were fixed in $10 \%$ neutral formol-saline, and portions of kidney were submitted to us for microdissection. These were prepared by the methods previously described (Darmady and Stranack, 1957). For microdissection of the vessels the length of maceration-time was reduced to 47 hours as opposed to 48 hours. 
E. M. DARMADY ET $A L$.: STUDY OF RENAL VESSELS BY MICRODISSECTION

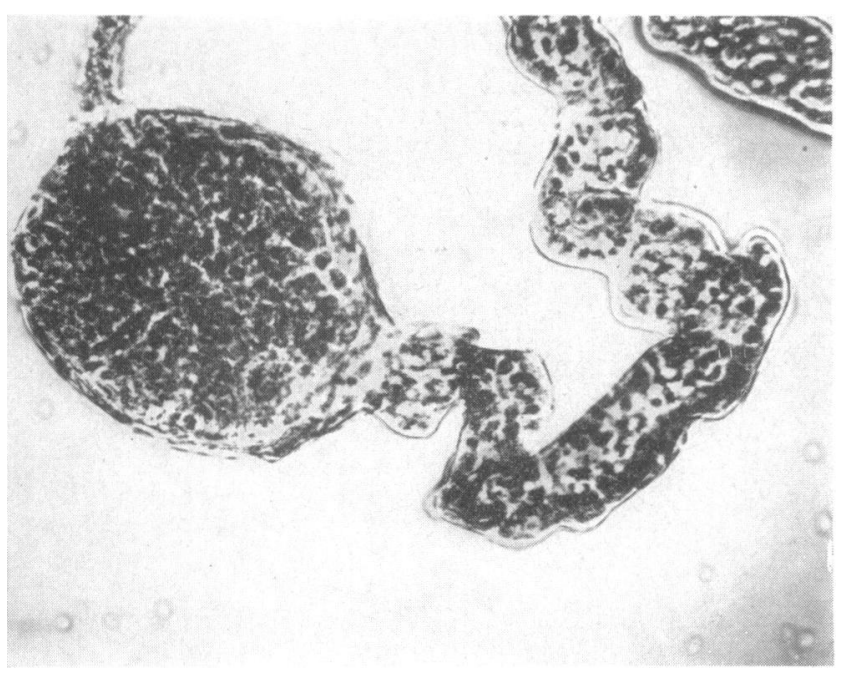

FIG. 1

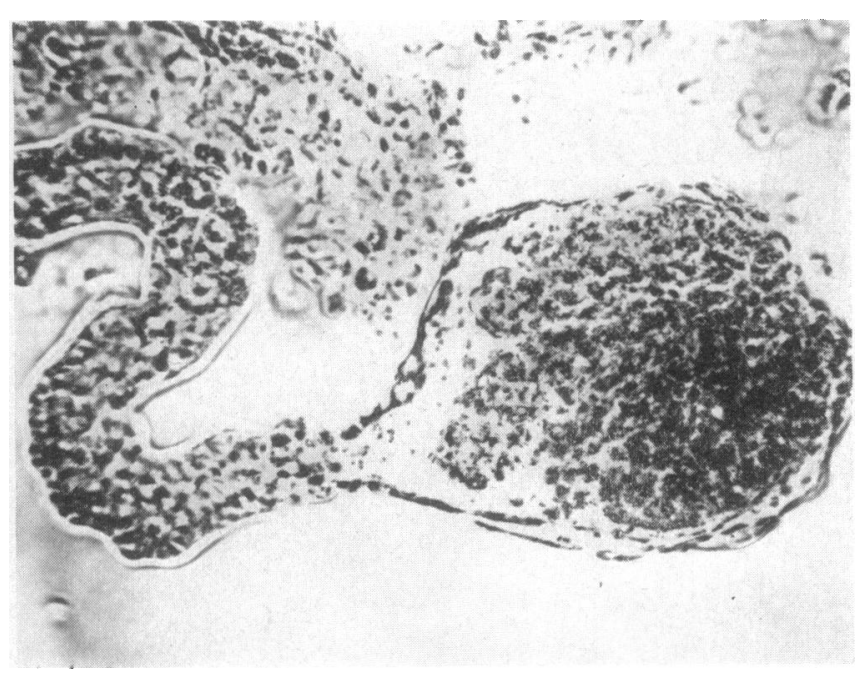

FIG. 3

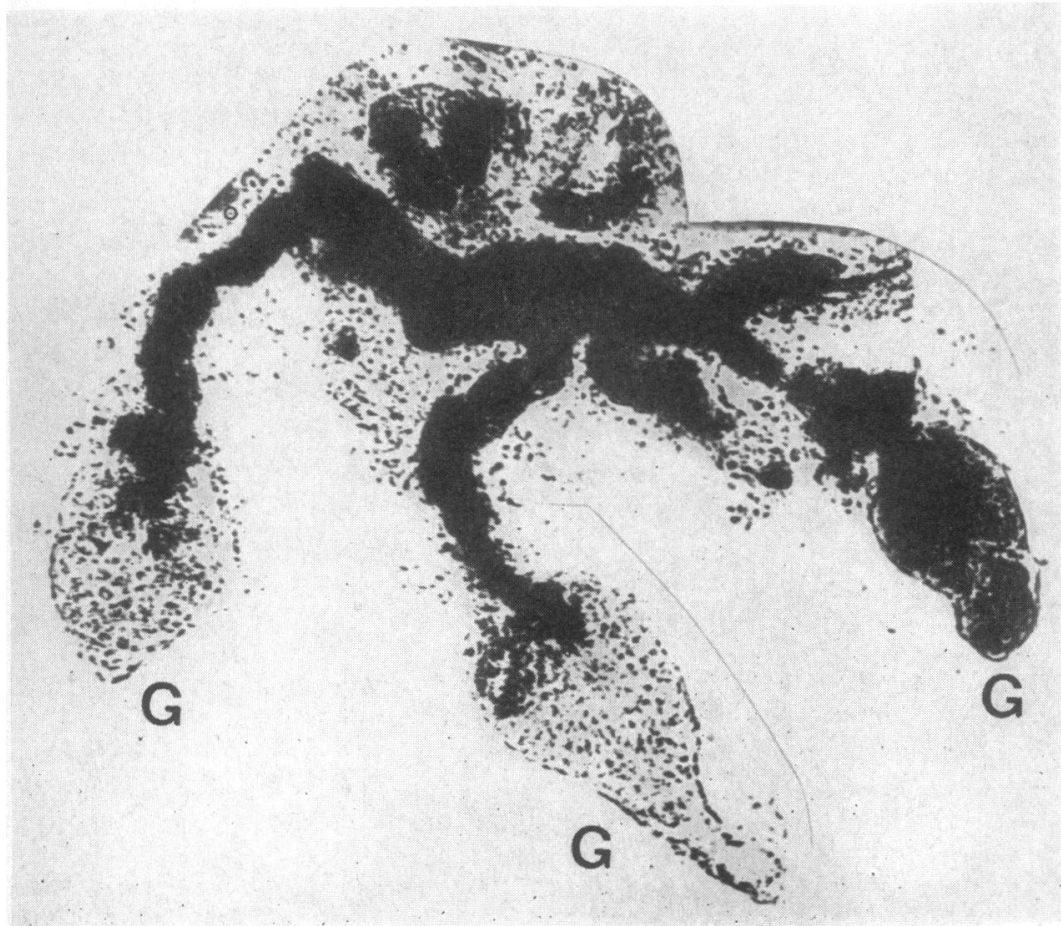

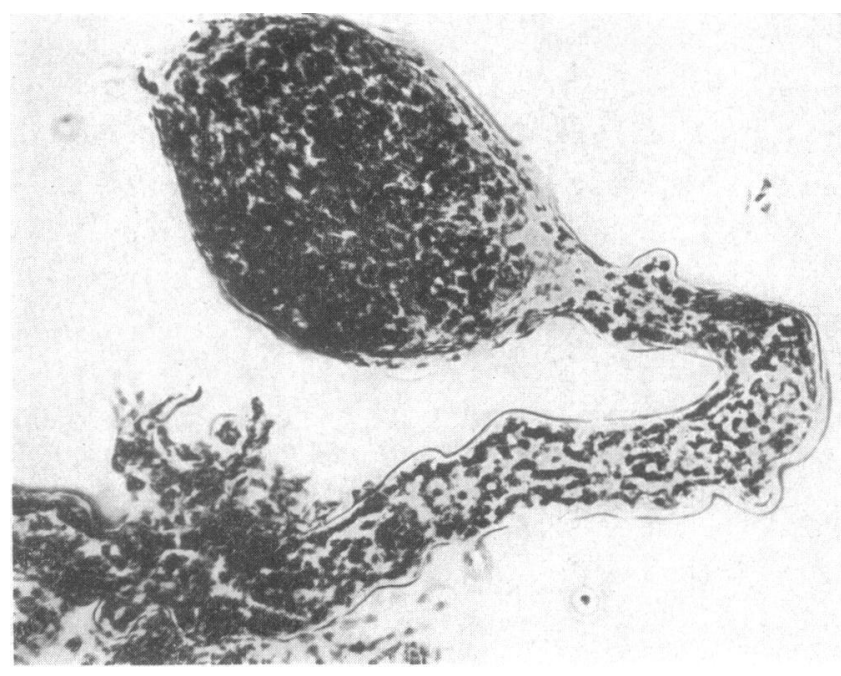

FIG. 2

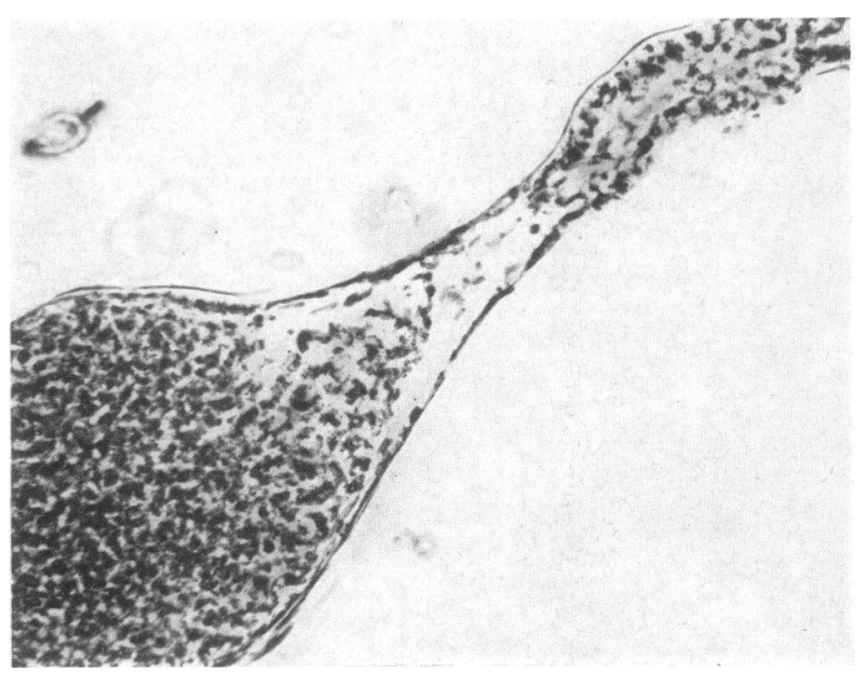

Fig. 4

FIgs. 1-4.-Case 1. Microdissection of a number of glomeruli showing the progressive epithelial desquamation of the first part of the proximal convoluted tubule. Note also the intense round-cell infiltration attached to the basement membrane of the tubule and the discrete desquamated cells lying in the lumen of tubule. $(\times 140$. Phase contrast. $)$

FIG. 5.-Case 3. Portion of interlobular artery. Note the marked intimal proliferation and aneurysmal dilatation of vessel and degeneration of the media. Note also the intense round-cell infiltration surrounding the vessel of three inctili (G), one of which is opaque, suggesting obliterative necrosis. $(\times 80$. Phase contrast.) 
E. M. DARMADY ET $A L$.: STUDY OF RENAL VESSELS BY MICRODISSECTION

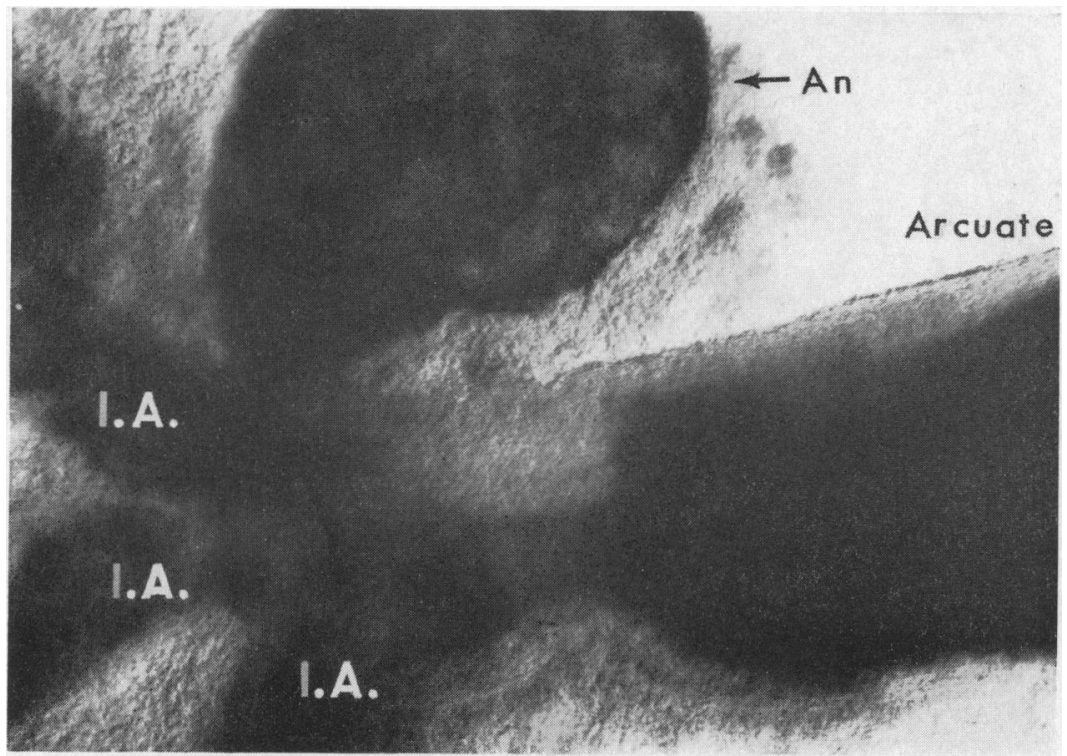

FIg. 6.-Case 4. Portion of the arcuate artery as it divides into three interlobular arteries (I.A.), from which an aneurysmal dilatation (An) has occurred. ( $\times 33$. Transmitted light.)
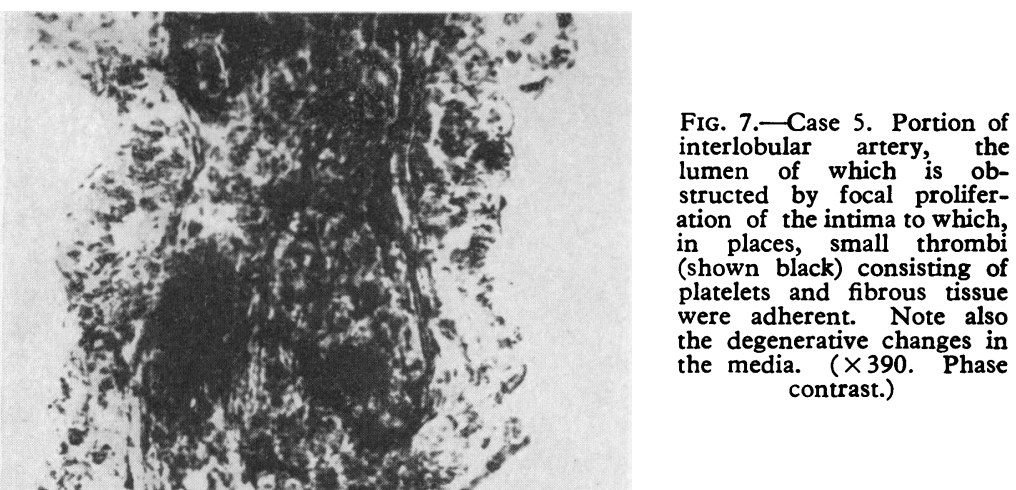

$\therefore$ is on

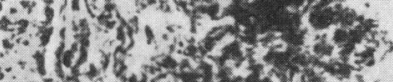

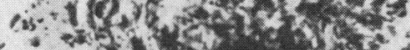
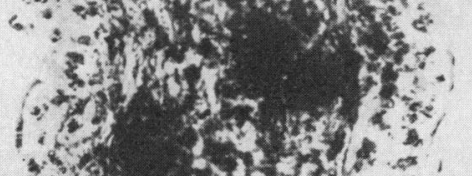

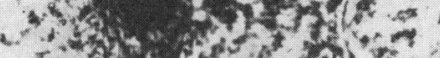

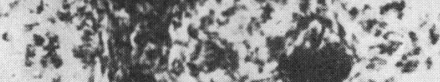

FIG. 8.-Case 6. Portion of the arcuate and interlobular artery. Note the gross focal proliferation of the intima and the area of $(\times 27$. Phase contrast.)
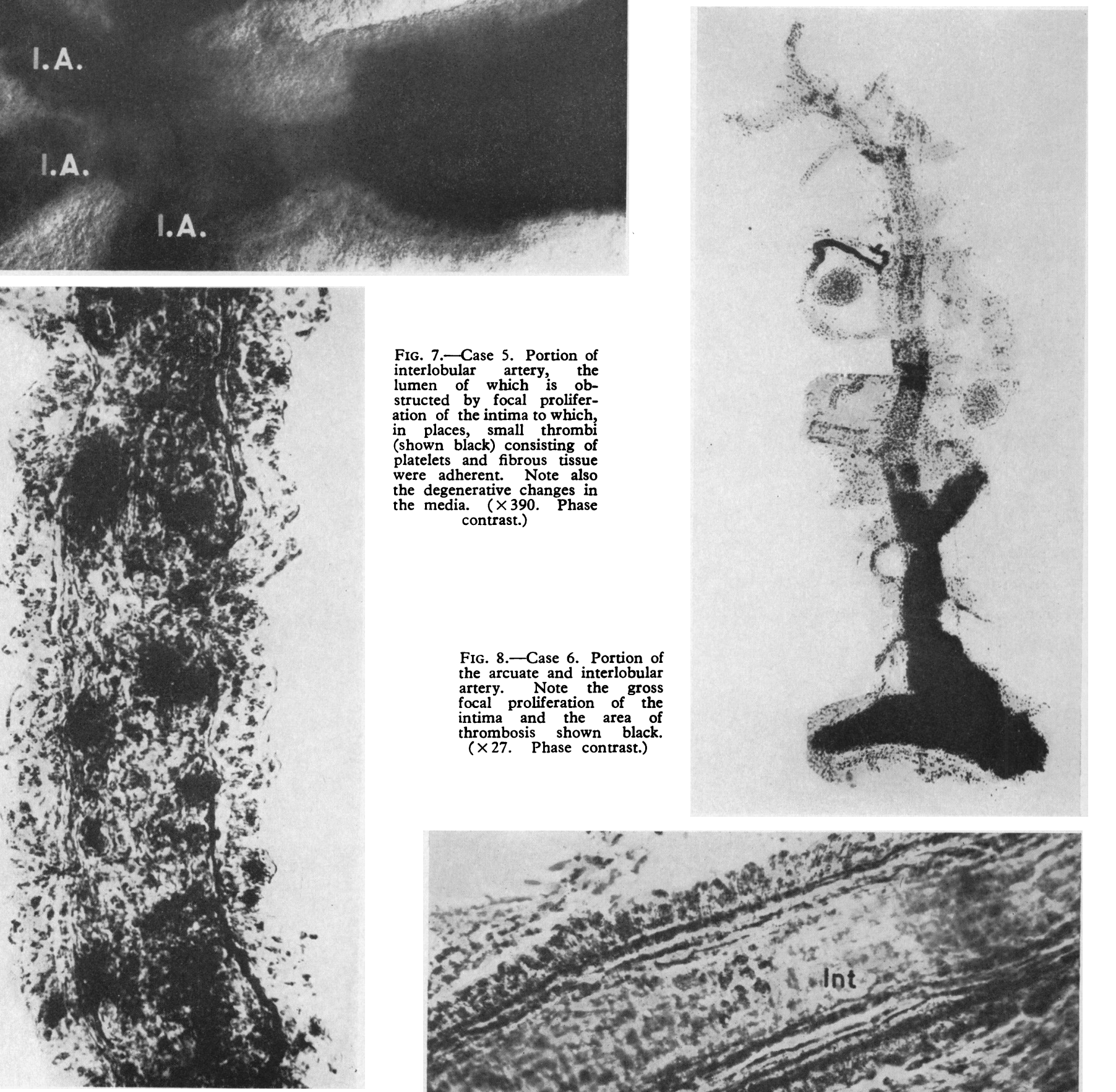

FIG. 9.-Case 7. Portion of the interlobular artery, from which surrounding fibrous tissue has been turned back. Note the proliferation of intima (Int) and reduplication of the media. ( $\times 400$. Phase contrast.)

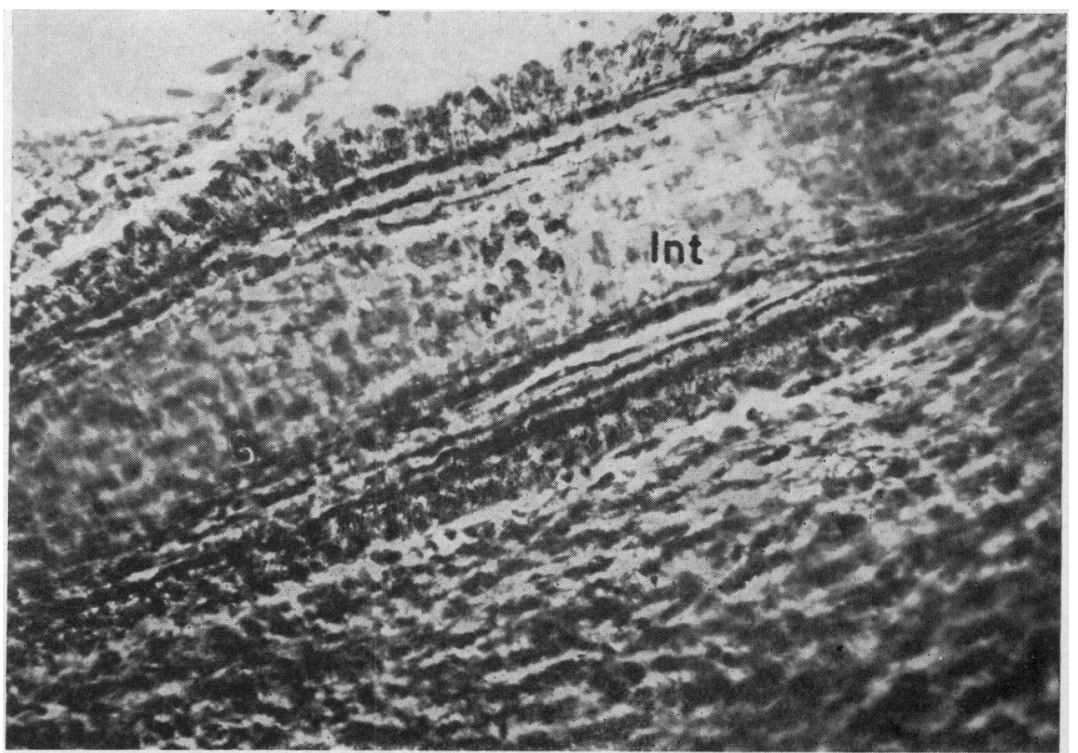


Seven kidneys were submitted to us following transplantation, the patients having died from 9 to 544 days previously. These are shown in the Table.

\begin{tabular}{|c|c|c|c|c|}
\hline $\begin{array}{l}\text { Case } \\
\text { No. }\end{array}$ & Age & Original Disease & Subsequent Renal Function & $\begin{array}{c}\text { Survival- } \\
\text { time after } \\
\text { Transplan- } \\
\text { tation }\end{array}$ \\
\hline 1 & 41 & $\begin{array}{l}\text { Chronic pyelo- } \\
\text { nephritis }\end{array}$ & 5 days' satisfactory function, & 9 days \\
\hline 2 & 38 & $\begin{array}{l}\text { Subacute glomerular } \\
\text { nephritis }\end{array}$ & $\begin{array}{l}4 \text { days' satisfactory function } \\
\text { followed by } 20 \text { days of moderate }\end{array}$ & 25 days \\
\hline 3 & 14 & " & $\begin{array}{l}\text { Anuric for first } 8 \text { days, followed } \\
\text { by } 16 \text { days of good function, } \\
\text { then anuria }\end{array}$ & 26 days \\
\hline 4 & 19 & $\begin{array}{l}\text { Chronic pyelo- } \\
\text { nephritis }\end{array}$ & Anuric throughout & 28 days \\
\hline 5 & 38 & Glomerulonephritis & $\begin{array}{l}\text { Oliguria for } 14 \text { days, followed by } \\
9 \text { days' satisfactory function }\end{array}$ & 33 days \\
\hline 6 & 34 & $\begin{array}{l}\text { Chronic pyelo- } \\
\text { nephritis } \\
\text { (calculus disease) }\end{array}$ & $\begin{array}{l}\text { Satisfactory function for approx. } \\
100 \text { days, followed by terminal } \\
\text { oliguria for } 26 \text { days }\end{array}$ & 126 days \\
\hline 7 & 40 & $\begin{array}{l}\text { Renal tuberculosis } \\
\text { and hypertension }\end{array}$ & $\begin{array}{l}544 \text { days' satisfactory function } \\
\text { throughout }\end{array}$ & 544 days \\
\hline
\end{tabular}

\section{Results}

As the histological findings are reported elsewhere (Dempster et al., 1964 ; Anderson, 1963), we do not propose to discuss these findings here, nor the methods used to suppress the rejection process, but to give the results found, in the chronological order of survival.

Case 1.-(Survived 9 days.) Changes similar to those described earlier (Darmady et al., 1955) were observed except that they were not so pronounced. The majority of nephrons showed a necrosis of the epithelium at the junction of the proximal convoluted tubule to the glomerulus. Evidence of desquamation of the cells is seen, which in more advanced lesions seems to be passing down the tubule. The basement membrane appears to be intact and not thickened. The suggested scheme of events is shown in Figs. 1, 2, 3, and 4 (Special Plate). Figs. 2 and 3 in particular demonstrate the focal nature of the round-cell infiltration and interstitial changes normally present in the first phase of the rejection process. Microdissection of the vessels shows no demonstrable change in the vessels themselves.

Case 2.-(Survived 25 days.) The tubular lesion recognized as a rejection phenomenon, described earlier, was present in a few of the proximal convoluted tubules examined. Some evidence of cystic dilatation of the tubule was seen in the middle third of the proximal convoluted tubule. The lumen of the dilated areas was filled with desquamated cells. Some of the tubules showed considerable epithelial disorientation. Examination of the vascular tree showed that the arcuate arteries contain focal areas of thrombosis and proliferation of the intima and in places degeneration of the media. The interlobular arteries were much more striking where in places the focal intimal thickening was such as almost to obliterate the vessels. In these areas were also seen a focal fibrosis and round-cell infiltration. In a few areas associated with occlusive change the glomerulus was opaque, suggesting obliteration or fibrosis. In some instances rupture of the vessels due to medial necrosis had occurred, resulting in a collection of amorphous material in the interstitial tissue, which failed to stain by congo red. Similar material was also seen in some of the tufts of the glomeruli.

Case 3.-(Survived 26 days.) The changes here were different from those seen in Case 2. The tubules showed no evidence of epithelial rejection syndrome. Principal changes were, however, seen in arcuate and interlobular arteries, where extremely focal areas of intimal thickening were observed. In places this was accompanied by thrombosis of the distal part of the vessel which extended to the glomeruli (Special Plate, Fig. 5). In many areas the glomeruli were opaque, suggesting complete obliteration of the vessel. Roundcell infiltration and fibrosis with some interstitial haemorrhage is also seen.

Case 4.-(Survived 28 days.) Microdissection showed that the whole of the arterial tree was affected by a marked focal change. The arcuate and larger interlobular arteries were particularly affected, and took the form of local degenerative changes of the media, which in places had developed into aneurysmal dilatations
(Special Plate, Fig. 6). In the smaller interlobular vessels the intima was thickened and showed evidence of overlying thrombosis. Many of the peripheral vessels appeared to be thrombosed, also in many cases the glomeruli opaque. All the proximal convoluted tubules appeared to be atrophic.

Case 5.-(Survived 33 days.) The changes here were somewhat similar to those seen in Case 3, although the interlobular arteries were particularly affected by extremely numerous focal areas of intimal thickening to which were adherent small areas of coagulation consisting of platelets and fibrous tissue. Widespread thrombosis of the vessels was not seen in this case, although reduction in the size of the lumen must be presumed because of opaque glomeruli seen in a number of areas (Special Plate, Fig. 7). The most striking feature was the gross interstitial fibrosis and the fact that $90 \%$ of the proximal convoluted tubules were reduced by more than half their normal diameter, the basement membrane being lined by a thin layer of flattened epithelium.

Case '6.-(Survived 126 days.) The feature of this case was the patchy nature of the lesions. Many of the proximal convoluted tubules were atrophic and were similar to those seen in Case 5. An interesting feature was the fact that the intact nephrons were not hypertrophic as might have been expected in view of the extent of atrophy of the remaining tubules. In this case marked intimal thickening of the interlobular artery was observed to such an extent that thrombosis was apparent in some of the arteries proximal to interlobular arteries. Widespread opaque changes were seen in the glomeruli (Special Plate, Fig. 8). Interstitial changes of fibrosis were not so obvious as in Case 5 .

Case 7.-(Survived 544 days.) The cause of death in this case was aplastic anaemia and coliform septicaemia. The renal function remained satisfactory until death. Microdissection showed a very widespread interstitial fibrosis throughout the entire kidney; this was particularly marked around the larger vessels-namely, the interlobar arcuate and to a less extent the interlobular arteries. Considerable difficulty was encountered in observing the lumen of the affected vessels, and it became necessary to divide and turn back the surrounding fibrous tissue. This exposure allowed observations to be made on the vessel itself, which showed considerable proliferation of the intima and reduplication of the media (Special Plate, Fig. 9). The smaller vessels, however, did not seem to be affected, and the number of glomeruli did not appear to be reduced unduly.

\section{Discussion}

Pathological changes described here fall into two categories. First, the changes which would seem to be part of the early immunological rejection process. The necrosis of epithelium, particularly in the first part of the proximal convoluted tubule, is similar to that described earlier. Second, proliferation of the intima and changes in the media of intrarenal arteries and arterioles. These have been previously described by Hume et al. (1955) in a patient who survived 180 days; Goodwin et al. (1963), 144 days ; Küss et al. (1962), 57 days; Porter et al. (1963), four cases 38-45 days ; Murray et al. (1963), 5 months 10 days; and also by Hamburger et al. $(1962,1963)$. So far the earliest case to show this lesion was that described by Parsons et al. (1963) (our Case 5); the patient survived 33 days.

In the patients (Cases 2 and 3) who survived 25 and 26 days the changes could be demonstrated in histological material; but they became much more obvious when microdissection was performed, since it was possible to follow the vessels in continuity. The striking features at this stage of the disease were the focal nature of the intimal thickening and the degeneration of the media, which have some similarity to those seen in periarteritis nodosa by microdissection.

The observation of the atrophy of the proximal convoluted tubule is of considerable importance. In Cases 4 and 5, with a survival of 28 and 33 days respectively, the proximal convoluted tubules had become atrophic. It was noticeable in these cases that the interstitial fibrosis appeared to be marked. In many vessels the focal areas of thrombotic-like material was seen adherent to the hypertrophic intima, but did not in fact occlude the lumen (Special Plate, Fig. 7). It is possible 
that the gradual reduction of blood-flow associated with the partial occlusion may be responsible for the atrophic changes seen in the proximal convoluted tubules. The fact that the remaining tubules do not develop compensatory hypertrophic change confirms the fact that the blood supply to the cortex is reduced over a period of time.

The distribution of vascular lesions is of some interest when taken in chronological order after transplantation, for those patients who survived the shortest time showed more changes in the smaller vessels, while those who survived for longer periods developed changes in the larger vessels.

The fact that six out of seven kidneys submitted to us had developed vascular changes suggests that this is commoner than was previously thought. It would seem that the variety of suppressive agents used to prevent the rejection syndrome are not themselves responsible for the vascular lesion, although radiation cannot be entirely excluded. It is not clear what factor is responsible for these changes, but as these are discussed by Dempster et al. (1964) they will not be repeated here. Porter et al. (1963) consider that the immunological basis may be responsible, and further thoughts are required on how the vascular lesion can be overcome once the initial stage has been passed.

\section{Summary}

The transplanted kidney of seven patients who survived 9, $25,26,28,33,126$, and 544 days has been examined by microdissection of the nephron and the renal arterial tree.

In two cases epithelial necrosis was seen in the first part of the proximal convoluted tubule. The desquamated cells had been shed into the lumen and passed down the tubule.

In six cases evidence of hypertrophy of the intima and degeneration of media with aneurysmal dilatation could be demonstrated in the interlobular and arcuate arteries and occasionally in the branches from the interlobar artery.

Microdissection demonstrates the extreme focal and progressive nature of the disease. The evidence here suggests that the shorter the period of time after transplantation the more likely will the more peripheral vessels be affected, and the longer the period of time the more likely are the larger vessels to be affected.

It is suggested that the arterial lesion probably occurs earlier in the syndrome than has previously been described.

This work was supported by Research Grant No. HE-05254 from the National Institute of Public Health Service, U.S.A.

We are indebted to Mr. W. J. Dempster and Professor C. V. Harrison for submitting kidneys for microdissection from Cases 1 , $2,3,4$, and 6 , the case histories of which and the suppressive agents used are detailed in the previous paper (Dempster et al., 1964); to Dr. C. K. Anderson for Case 5, previously reported by Parsons et al. (1963); and to Professor R. Küss and Dr. M. Legrain for Case 7, previously reported by Küss et al. (1963).

\section{REPERENCES}

Anderson, C. K. (1963). Quoted by Parsons et al. (1963).

Calne, R. Y., Loughridge, L. W., MacGillivray, J. B., Zilva, J. F., and Levi, A. J. (1963). Brit. med. F., 2, 645 .

Darmady, E. M., Dempster, W. J., and Stranack, F. (1955). F. Path. Bact., 70, 225.

- and Stranack, F. (1957). Brit. med. Bull., 13, 21.

Dempster, W. J. (1953). Brit. F. Surg., 40, 447.

- Harrison, C. V., and Shackman, R. S. (1964). Brit. med. 7., 2, 969.

Goodwin, W. E., Kaufman, J. J., Mims, M. M., Turner, R. D., Glassack, R., Goldman, R., and Maxwell, M. M. (1963). J. Urol., 89, 13.

Hamburger, J., Vaysse, J., Crosnier, J., Auvert, J., and Dormont, J. (1963). Bull. Soc. méd. Hôp. Paris, 114, 225.

7. Med., 32, 854. Lalanne, C. M., and Hopper, J. (1962). Amer.

Hume, D. M., Merrill, J. P., Miller, B. F., and Thorn, G. W. (1955). F. clin. Invest., 34, 327.

Küss, R., Legrain, M., Mathé, G., Nedey, R., and Camey, M. (1962). Rev. franç. Etud. clin. biol., 7, 1048.

Murray, J. E., Merrill, J. P., Dammin, (1963), Presse méd., 71, 445.

Murray, J. E., Merrill, J. P., Dammin, G. J., Dealy, J. B., Alexandre, G. W., and Harrison, J.' H. (1962). Ann. Surg., 156, 337. New Harrison, J. H., Wilson, R. E., and Dammin, G. J. (1963). New Engl. 7. Med., 268, 1315 .

Parsons, F. M., Markland, C., Raper, F. P., and Fox, M. (1963). Brit. med. 7., 1, 930.

Porter, K. A., Thomson, W. B., Owen, K., Kenyon, J. R., Mowbray, J. F., and Peart, W. S. (1963). Ibid., 2, 639.

\title{
Application of Thermography to the Problem of Placental Localization: Preliminary Communication
}

\author{
RAYMOND J. YOUNG,* M.B., B.S.
}

[With Special Plate]

Brit. med. F., 1964, 2, 978-981

Most obstetricians would agree that a method for accurate localization of the placenta in a pregnant uterus would constitute a significant contribution to antenatal care and management of labour. For instance, many women who have a small ante-partum haemorrhage are confined to hospital for many weeks and may eventually come to examination under anaesthesia with all its attendant risks to mother and foetus. This is sound and common practice, yet it is a reflection of the faith which obstetricians have in techniques of placental localization available at the moment. There is little to choose between the present techniques of placental localization, since all of them involve the use of ionizing radiations.

Radiological techniques may involve the skilled interpretation of soft-tissue $x$-ray films. This method may be augmented by the use of contrast media in the bladder and rectum. Good results have been reported in relation to placenta praevia. Donald (1964a) reports a 97\% accuracy from his unit. More elaborate radiological techniques involving the use of intravascular contrast media are usually applied to special cases and are not in routine clinical use.

Radioactive isotopes have successfully demonstrated the placental site and have given a clue to problems of placental function (Browne and Veall, 1953 ; Hibbard, 1962). However, a low, acceptable dose of radio-isotope has the disadvantage of making localization of placentae on the posterior uterine wall very difficult and uncertain. The techniques involving

* Registrar to Department of Obstetrics, Bedford General Hospital. 